A SPECIAL ISSUE FOR THE $6^{\text {TH }}$ SCIENTIFIC INTERNATIONAL CONFERENCE

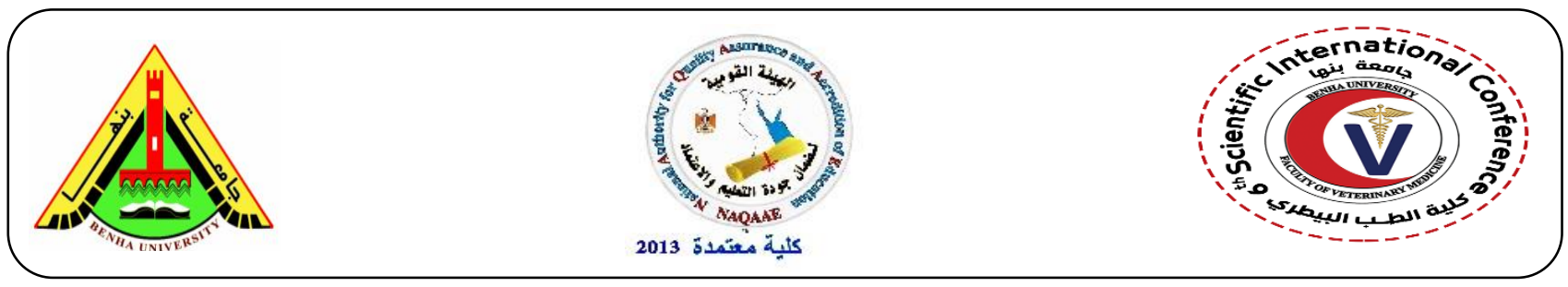

\title{
Potential Role of Thymoquinone in Imidaclopride Induced Testicular Toxicity in Male Albino Rats
}

\author{
Samy A. Hussein ${ }^{1 *}$; Shaaban S. Khalaf-Allah ${ }^{2}$; Hanan A. Tag El-Din ${ }^{3}$; Aziza Amin ${ }^{4}$ and Randa \\ M. Khallaf ${ }^{1}$ \\ ${ }^{1}$ Department of Biochemistry, Faculty of Vet. Med., Benha University, Egypt. \\ ${ }^{2}$ Department of Animal health, Faculty of Vet. Med., Benha University, Egypt. \\ ${ }^{3}$ Department of Biochemistry and food deficiency, Animal health research institute, Dokki, Giza, \\ ${ }^{4}$ Department of Pathology, Faculty of Vet. Med., Benha University, Egypt.
}

*Corresponding author: samyaziza@yahoo.com- samy.aziza@Futm.bu.edu.eg

\section{A B S T R A C T}

Medicinal plants have played a vital role in treatment of variety of male reproductive system disorders. Thymoquinone (TQ), is the main active components of Nigella sativa, exhibited very useful biomedical effects such as anti-inflammatory, antioxidant, antimicrobial, antiparasitic, anticancer and hypoglycemic effects. The aim of this study was to evaluate the probable protective effect of thymoquinone (TQ) on imidaclopride (IMI) induced testicular damage in rats. Forty male albino rats were classified randomly into four equal groups. Group1 (control). Group2 (IMI): rats received IMI orally day after day over a period of 8 weeks at a dose level of $21.2 \mathrm{mg} / \mathrm{kg} \mathrm{b.w}(1 / 20$ LD50). Group3 (TQ): rats received TQ orally once per day at a dose of $10 \mathrm{mg} / \mathrm{kg}$ body weight/day for 8 weeks. Group 4 (TQ+IMI): rats received TQ (10 $\mathrm{mg} / \mathrm{kg}$ body weight) orally for 4 days before and along with the administration of (IMI) over a period of 8 weeks. At the end of the experiment blood samples were collected for testosterone and estradiol (E2) hormones determination, semen samples for sperm characteristics evaluation and testes for the determination of MDA, SOD, CAT, GSH and also, for histopathological examination. The obtained results reported the endocrine disruption effect of IMI resembled in marked decline in testosterone hormone, while E2 was markedly elevated. At the same time there was an insignificant reduction at sperm characteristics (motility, viability and count), while there was a highly significance elevation at sperm abnormality. Oxidative stress results showed a significant increase in testicular tissue MDA in imidaclopride intoxicated rats. However, testicular SOD activity, catalase, and GSH concentration were markedly decreased. TQ protection to IMI induced testicular toxicity in rats caused a significant improvement of all previous parameters. These results suggested possible protective role of thymoquinone to improve testicular damage by attenuating the endocrine disruptor effect of IMI on some reproductive hormones, sperm characteristics alterations or oxidative stress markers in rats through its antiinflammatory activities and free radical scavenging properties.

Key words: Imidaclpride (IMI), Testicular damage, TQ, endocrine disruption.

$$
\text { (http://www.bvmj.bu.edu.eg) }
$$

(BVMJ-34(3):64-82, 2018) 


\section{INTRODUCTION}

Plants and its derivatives played a key role in world health and have long been known to possess biological activity. Thirty percent of all modern drugs are derived from plants (Burns., 2000). In addition, plants have a long folklore of use in aiding fertility, including fertility-enhancing properties (D'Cruz, 2010). Nigella sativa seeds are used extensively in traditional medicine of many countries. It has been used for treatment of many diseases owing to the reported antiviral, anti-inflammatory, anti-schistosomiasis and immune- modulatory activities (UZ et al., 2008). Nigella Sativa seed contains a complex mixture of more than 100 compounds (Ahmad et al ., 2013). Nigella sativa oil increase the number of Leydig cells in rat testes (Mukhallad et al., 2009). Most of the therapeutic properties of Nigella sativa are due to the presence of the polyphenol thymoquinone (TQ) (Ali and Blunden. 2003)which is major active component of Nigella sativa oil (Gali-Muhtasib et al.,2006). TQ have been known by their hypoglycemic, hypolipidemic and radical scavenging activity (El-Dakhakhny et al., 2002). Gokçe et al. (2010) confirmed that TQ treatment has protective effects on testicular parameters. Previous data suggest that the seeds oil and TQ exhibited spermioprotective effect against testes damage (Haseena et al., 2015). Antioxidant property of TQ is attributed to the quinine structure of TQ molecule (Gokce et al., 2011) and the easy access to sub cellular compartments thus facilitating the ROS scavenging effect (Badary et al., 2000). TQ was shown to inhibit non-enzymatic lipid peroxidation. This leads to decreased oxidative stress and protection of the antioxidant enzymes of testis (Ismail et al., 2010). Antioxidants, which form a diverse group of compounds with different properties, operate by inhibiting oxidant formation, intercepting oxidants and repairing oxidant induced injuries (Ergüder et al., 2007).

According to an estimate, about 5.2 billion pounds of pesticides are used worldwide per year (Hakeem et al., 2016). The adverse effects on the male reproductive system include direct damage of the cells or disruption of the developmental pathways directly or through endocrine modifications. Toxic pesticides are known to cause germ cells disintegration, loss of Leydig cells, degeneration of seminiferous tubules, alternation in spermatogenesis, depletion in semen quality, teratospermia and endocrine disruption (Sharma and Goyal. 2014). Endocrine disruptor properties are also known to adversely impair the reproductive competence of males. Its adverse effects are related with their ability to interfere with sex steroid action, which finally causes adverse effects to the adult reproductive system (Kapoor et al., 2011). Imidaclopride is a chlorinated analog of nicotine, which belongs to the class of neonicotinoid insecticides. IMI has low vapor pressure and the technical product (94.0\% IMI) has a moderate order of toxicity with respect to ingestion in the rat but appears to be less toxic when absorbed by inhalation (Mizzel and Sconyers, 1992). IMI is the fastest growing insecticide in sales globally because of its low selectivity for insects and apparent safety for humans (Matsuda et al., 2001). Recently, IMI has raised concern because of its signs of possible endocrine disrupters (Berny et al., 1999). Although few reports on mammalian toxicity of IMI are available but the information on oxidative stress of this compound after long term repeated exposure is publically 
unavailable (EL-Gendy et al., 2010). Accordingly, the present study was carried out to investigate the protective effect of TQ on IMI subacute toxicity induced some hormonal changes, semen alteration, oxidative stress, and histopathological changes in testes of male albino rats.

\section{MATERIALS AND METHODS}

\subsection{Experimental animals:}

Forty white male albino rats of 8-10weeks old age and average body weight $150-200 \mathrm{~g}$ were used in this study. Rats were housed in separated polycarbonate cages (10 per cage) and they were kept on a well-balanced ration and fresh clean drinking water ad-libitum. Rats were kept at a constant environmental and nutritional condition throughout the whole period of experiment. All rats were left for 15 days for acclimatization before the beginning of the experiment.

\subsection{Chemicals and antioxidant:}

Chemicals and the antioxidant used in the present study were:

\subsubsection{Imidaclopride}

IMI grade (96\% active ingredient) were gifted from Pesticides Analysis Department, Central Agricultural Pesticides Lab., Dokki, Egypt.

-IMI solution preparation:

$1000 \mathrm{mg}$ of IMI was mixed in $3 \mathrm{ml}$ Dimethyl sulfoxide (DMSO) and complete dissolving was obtained. Then propylene glycol was added till $60 \mathrm{ml}$ with vortex stirring to reach a final concentration of $21.2 \mathrm{mg} \mathrm{IMI} / \mathrm{ml}$ of Solution.

\subsubsection{Thymoquinone:}

\section{TQ}

(2-isopropyl-5-methyl-1,4benzoquinone) was purchased from SigmaAldrich Chemical Co. (St. Louis, MO, USA). It was used as a protective agent to testicular disorders at a dose level $10 \mathrm{mg} / \mathrm{kg}$ b.w (Nagi and Mansour, 2000)
-TQ solution preparation:

$300 \mathrm{mg}$ of TQ was mixed in $10 \mathrm{ml}$ ethanol absolute at room temperature until complete dissolving was obtained. Physiological saline $(10 \% \mathrm{NaCl})$ at room temperature was added till $150 \mathrm{ml}$ with vortex stirring to obtain a final concentration of 10 $\mathrm{mg}$ TQ / $\mathrm{ml}$ of solution.

\subsubsection{Other chemicals used in this study:}

(Propylene glycol, DMSO, ethanol and normal saline) were of the highest purified grades available purchased from El Gomhouria Company for Trading Chemicals and Medical Appliances, Egypt.

\subsection{Experimental design:}

After acclimatization to the laboratory conditions, the animals were randomly divided into four groups (10 rats each) placed in individual cages and classified as follow:

Group 1 (control group): Rats received tap water, fed on basal ordinary diet during the entire experimental period of 8 weeks.

Group 2 (IMI treated group): Rats received IMI orally by stomach tube day after day over a period of 8 weeks to induce testicular disorders in rats at a dose level of $21.2 \mathrm{mg} / \mathrm{kg}$ b.w (1/20 LD50) which is $424 \mathrm{mg} / \mathrm{kg}$ body weight (United states EPA, 1995).

Group 3(TQ treated group): Rats received TQ orally once per day at a dose of $10 \mathrm{mg} / \mathrm{kg}$ body weight/day for 8 weeks.

Group 4 (TQ + IMI treated group): Rats treated with TQ orally by the stomach tube once per day at a dose of $10 \mathrm{mg} / \mathrm{kg}$ body weight 4 days before and along with the administration of IMI (day after day) over a period of 8 weeks.

\subsection{Sampling:}

Blood samples, semen samples and testes were collected from the animals of each group (control and experimental 
groups) at the end of the eight weeks for G1, G2 and G3 and after 60 days for G4.

\subsubsection{Blood samples:}

Blood samples for serum separation were collected from the orbital sinus of each animal by using heparinized capillary tubes at the end of each experimental period and after overnight fasting in dry, clean and screw capped tubes. Serum was separated by centrifugation at 2500r.p.m for 15 minutes. The clean, clear serum was separated by automatic pipette and received in dry sterile samples tube. Then kept in a deep freeze at $20^{\circ} \mathrm{C}$ until used for subsequent hormonal determination of (testosterone and (E2)).

\subsubsection{Semen samples:}

Cauda epididymis was used for semen and sperm characteristics examination.

\subsubsection{Testes samples for biochemical analysis:}

At the end of the experiment the rats were sacrificed under light ether anesthesia. Both testes were isolated immediately, weighed and then one of them was cleaned by rinsing with cold saline and stored at $-20{ }^{\circ} \mathrm{C}$ for subsequent biochemical analyses. All testes samples were analyzed for the determination of malondialdehyde (MDA), superoxide dismutase (SOD), catalase (CAT) and reduced Glutathione (GSH). Also, comet assay was detected.

\subsubsection{Testicular tissue preparation for antioxidant determination:}

Briefly, testicular tissues were cut, weighed and minced into small pieces, homogenized with a glass homogenizer in 9 volume of ice-cold $0.05 \mathrm{mM}$ potassium phosphate buffer (pH7.4) to make $10 \%$ homogenates. The homogenates were centrifuged at 6000 r.p.m for 15 minutes at 4 ${ }^{\circ} \mathrm{C}$ then the resultant supernatant was used for the determination of the following parameters: MDA, SOD and CAT.

About $0.2 \mathrm{~g}$ of testicular tissues were minced into small pieces homogenized with a glass homogenizer in $0.4 \mathrm{ml}$ of $25 \%$ metaphosphoric acid (MPA) (ref. No.: 253433-4, Sigma-Aldrich, Germany), then $1.4 \mathrm{~mL}$ of distilled water was added, mixed, incubated for 1 hour and centrifuged for $10 \mathrm{~min}$ at 3,000 r.p.m then the clean supernatant was removed and used for determination of GSH concentration.

\subsubsection{Histopathological examination:}

The other testis was preserved in $10 \%$ buffered neutral formalin and subjected for microscopical examination.

\subsection{Methodology:}

\subsubsection{Hormonal determination:}

Quantitative determination of serum testosterone concentration was carried out using ELISA kit (The CalbiotechInc. Co) with a catalog No. TE187S.Quantitative determination of estradiol levels by chemiluminescent immunoassay using the Access Immunoassay Systems was carried out using (Beckman Coulter. Co) with a catalog No. 33540 .

\subsubsection{Determination of sperm characteristics:} Epididymal sperm collection and preparation:

Determination of sperm count following the method of Yokoi et al. (2003), cauda epididymis was isolated and immediately minced in physiological normal saline $(5 \mathrm{ml})$, gently rocked on a shaker for $10 \mathrm{~min}$ and then incubated for $2 \mathrm{~min}$ at $37{ }^{\circ} \mathrm{C}$ to allow spermatozoa to leave the epididymal tubules. The supernatant fluid was mixed (1:100) with a solution containing $1 \mathrm{ml}$ formalin (35\%), $5 \mathrm{~g}$ sodium bicarbonate, and $25 \mathrm{mg}$ eosin in 100 $\mathrm{ml}$ distilled water. An aliquot of the diluted sperm suspension $(10 \mu \mathrm{l})$ was transferred to 
each counting chamber of a hemocytometer and was allowed to stand for $5 \mathrm{~min}$ then counted under a light microscope at $\times 200$ magnification. Determination of sperm viability. For each rat, $20 \mu \mathrm{l}$ of sperm suspension was carefully mixed with an equal volume of Eosin-Nigrosin stain, and a thin film was spread on a clean slide. Two hundred sperms were randomly examined for each sample at $\times 400$ magnification and the percentage of viable sperms were calculated. Dead sperms were stained pink and live sperms remained unstained (Wyrobek et al., 1983).

Determination of sperm motility. According to Sönmez et al. (2005), fluid from the cauda epididymis was taken by a pipette and diluted to $2 \mathrm{ml}$ with the buffer solution. The percentage of motility was estimated microscopically within $2-4 \mathrm{~min}$ at $\times 400$ magnification and was expressed as a percentage of motile sperms to the total sperm count.

Determination of sperm abnormalities. Following the method reported by Evans and Maxwell (1987), 300 sperms were microscopically counted per slide at $\times 400$ magnification and the percentages of morphologically abnormal sperms were recorded.

\subsubsection{Antioxidants determination:}

Testicular tissues MDA concentrations were determined according to the method adapted by Mesbah et al. (2004), testicular (SOD) activity (Nishikimi et al., 1972) and testicular CAT activity (Aebi, 1984). Testiclar tissue (GSH) detection by colorimetric method was carried out using kit (Bio Diagnostic. Co) with a catalog No.: GR 2511.

\subsubsection{Histopathological examination:}

The other testis was carefully examined by naked eyes for detection of any abnormalities and immediately fixed in $10 \%$ natural buffered formalin. Then after proper fixation, the samples were dehydrated in ascending grades of ethyl alcohol, then cleared in xylol, embedded in paraffin and finely blocking occurred. These samples were sectioned at $5 \mu \mathrm{m}$ in thickness and stained with hematoxylin and eosin ( $\mathrm{H}$ and $\mathrm{E}$ ) for histopathological examination according to (Dray and Walling, 1976).

\subsection{Statistical analysis:}

The results were expressed as mean $\pm \mathrm{SE}$ using SAS computerized program v. 9.2 (SAS, 2008) program to calculate the analysis of variance. The data were analyzed using one-way ANOVA to determine the statistical significance of differences among groups. Duncan's test was used for making a multiple comparison among the groups for testing the inter-grouping homogeneity. Values were considered statistically significant when $\mathrm{p}<0.05$.

\section{RESULTS:}

\section{Hormones:}

The obtained results in table (1) exhibited that, (G2) recorded an insignificant decline in serum testosterone level when compared with (G1).

Whereas, (G3) demonstrated an insignificant decline when compared with control group (G1). Moreover, (G4) revealed insignificant increase in serum testosterone concentration when compared with (G2).

Concerning serum E2 level, (G2) showed an insignificant increase when compared with control group (G1). On the same level, (G3) demonstrated an insignificant increase in E2 level when compared with control group (G1) .Moreover , an 
insignificant decrease in E2 levels was detected in G4 in comparing with (G2) .

\section{Semen characteristics:}

The obtained results presented in table (2) indicated that, (G2) revealed an insignificant decrease in sperm characteristics (motility, viability and count), while sperm abnormality showed a highly significant increase $(\mathrm{P} \leq 0.01)$ when compared with control group $(\mathrm{G} 1)$.

As regard (G3) demonstrated an insignificant increase in sperm motility while showed no marked change in sperm abnormality when compared with control group (G1). However, (G3) revealed a significant decrease $(\mathrm{P} \leq 0.01)$ in sperm viability, while showed a significant increase $(\mathrm{P} \leq 0.01)$ in sperm count when compared with control group (G1).

(G4) revealed an insignificant increase in sperm motility, viability and count when compared with (G2). While it showed an insignificant decrease in sperm abnormality when compared with (G2).

\section{Antioxidants parameters:}

The obtained results presented in table (3) indicated that, (G2) showed a significant increase $(\mathrm{P} \leq 0.01)$ in testicular tissue MDA level when compared with control group (G1). As regard (G3) demonstrated no marked change when compared with control group (G1). In addition, (G4) protected rats revealed a significant decrease $(\mathrm{P} \leq 0.01)$ in testicular tissue MDA activity when compared with (G2).

the mean level of SOD activity at G2 was insignificantly declined in testicular tissue when compared with control group (G1). Whereas, (G3) demonstrated a significant elevation $(\mathrm{P} \leq 0.01)$ when compared with control group (G1). Incidentally, (G4) revealed a significant increase $(\mathrm{P} \leq 0.01)$ in testicular tissue SOD activity when compared with (G2).

The obtained data revealed that, $(\mathrm{G} 2)$ showed a significant decrease $(\mathrm{P} \leq 0.01)$ in testicular tissue catalase activity when compared with control group (G1). Whereas, (G3) demonstrated an insignificant decline when compared with control group (G1). While, catalase activity in (G4) testicular tissues revealed a significant increase $(\mathrm{P} \leq 0.01)$ when compared with (G2).

(G2) revealed a highly significant decrease $(\mathrm{P} \leq 0.01)$ in testicular tissue GSH activity when compared with control group (G1). Also, GSH level in testicular tissues recorded a significant decrease in G3 compared with control group (G1). Moreover, (G4) revealed a significant increase $(\mathrm{P} \leq 0.01)$ in testicular tissue GSH activity when compared with (G2).

\section{$\underline{\text { Histopathological examination }}$}

\section{Group 1 (Control rats)}

Histopathological examination showed normal histological structure of seminiferous tubules and interstitial tissues as well as tunica albuginea (Fig. 1).

Group 2 (Rats treated with IMI $21.2 \mathrm{mg} / \mathrm{kg} \mathrm{b.}$ $w)$ :

The microscopical examination revealed a marked increase in the thickness of tunica albuginea with sub-capsular edema and severe congestion of sub-capsular blood vessels (Fig. 2\&3). Extensive necrosis of spermatogenic cells of seminiferous tubules with stop of spermatogenesis was also demonstrated (Fig. 4)

\section{Group-3 (TQ protected group)}

Histopathological examination showed normal histological structure of the germinal 
epithelium of seminiferous tubules and interstitial tissues.

Group-4 $(T Q+I M I)$ :

The microscopical examination revealed less prominent histopathological changes when compared with the group treated with imidaclopride for the same period. appeared somewhat normal in most tubules. Most of the seminiferous tubules restored its normal structure and the spermatogenesis processes are normal (Fig. 7)

Tunica albuginea appeared normal. Most of the seminiferous tubules were compact with each other (Fig.6). The spermatogenic layers

Table (1): Effect of TQ administration on serum (testosterone, estradiol(E2) levels in imidaclopride intoxicated male rats.

\begin{tabular}{ccl}
\hline & $\begin{array}{c}\text { Testosterone } \\
(\mathrm{ng} / \mathrm{mL})\end{array}$ & $\begin{array}{l}\text { Estradiol } \\
(\mathrm{pg} / \mathrm{mL})\end{array}$ \\
\hline Exp. group & $5.21 \pm 0.573^{\mathrm{ab}}$ & $54.67 \pm 2.96^{\mathrm{ab}}$ \\
IMI (G2) & $3.99 \pm 0.438^{\mathrm{bc}}$ & $57.17 \pm 3.38^{\mathrm{ab}}$ \\
TQ $(\mathrm{G} 3)$ & $3.47 \pm 0.369^{\mathrm{bc}}$ & $63.17 \pm 1.11^{\mathrm{a}}$ \\
TQ $+\mathrm{IMI}(\mathrm{G} 4)$ & $4.91 \pm 0.437^{\mathrm{abc}}$ & $52.00 \pm 4.81^{\mathrm{ab}}$ \\
\hline
\end{tabular}

Data are presented as (Mean \pm S.E). S.E: Standard error. $n=6 /$ group.

Mean values with different superscript letters in the same column are significantly different at $(\mathrm{P} \leq 0.01)$.

Table (2): Effect of TQ administration on semen parameters and sperm characteristics [motility, viability, abnormality and sperm count $(\times 106 / \mathrm{ml})]$ concentration in imidaclopride intoxicated male rats.

\begin{tabular}{|c|c|c|c|c|}
\hline Exp. group & $\begin{array}{c}\text { Sperm motility } \\
(\%)\end{array}$ & $\begin{array}{c}\text { Sperm viability } \\
(\%)\end{array}$ & $\begin{array}{c}\text { Sperm abnormality } \\
(\%)\end{array}$ & $\begin{array}{l}\text { Sperm Count } \\
\left(\times 10^{6} / \mathrm{ml}\right)\end{array}$ \\
\hline Control (G1). $n=10$ & $43.00 \pm 2.00^{\mathrm{a}}$ & $96.90 \pm 0.378^{\mathrm{a}}$ & $10.60 \pm 1.05^{\mathrm{c}}$ & $130.96 \pm 4.143^{\mathrm{cd}}$ \\
\hline $\operatorname{IMI}(\mathrm{G} 2) . \mathrm{n}=10$ & $38.00 \pm 3.51^{\mathrm{a}}$ & $93.20 \pm 1.083^{\mathrm{ab}}$ & $20.70 \pm 2.31^{\mathrm{a}}$ & $124.70 \pm 9.537^{\mathrm{cd}}$ \\
\hline TQ (G3). $n=7$ & $50.00 \pm 1.54^{\mathrm{a}}$ & $92.00 \pm 2.047^{\mathrm{b}}$ & $11.57 \pm 1.41^{\mathrm{c}}$ & $187.22 \pm 17.234^{b}$ \\
\hline TQ+IMI (G4). n=7 & $39.49 \pm 3.13^{\mathrm{a}}$ & $94.00 \pm 2.370 \mathrm{a}^{\mathrm{b}}$ & $16.71 \pm 1.63^{\mathrm{ab}}$ & $144.40 \pm 16.559^{\mathrm{cd}}$ \\
\hline
\end{tabular}

Data are presented as (Mean \pm S.E). S.E: Standard error.

Mean values with different superscript letters in the same column are significantly different at $(\mathrm{P} \leq 0.01)$.

Table (3): Effect of (TQ) administration on testicular oxidative stress markers [Malondialdehyde (MDA), Superoxide Dismutase (SOD), Catalase,(CAT) and Glutathione (GSH)] levels in IMI intoxicated male rats . 
Potential Role of Thymoquinone in Imidaclopride Induced Testicular Toxicity in Male Albino Rats

\begin{tabular}{cllll}
\hline Exp. group Parameter & MDA (nmol/gm) & SOD $(\mathrm{u} / \mathrm{g})$ & Catalase $(\mathrm{u} / \mathrm{g})$ & GSH $(\mathrm{mmol} / \mathrm{g})$ \\
\hline Control (G1) & $2.92 \pm 0.146 \mathrm{~b}$ & $41.62 \pm 2.023 \mathrm{~b}$ & $1.61 \pm 0.068 \mathrm{a}$ & $2.45 \pm 0.024 \mathrm{a}$ \\
IMI(G2) & $4.91 \pm 0.518 \mathrm{a}$ & $33.52 \pm 4.656 \mathrm{~b}$ & $0.84 \pm 0.167 \mathrm{~b}$ & $1.10 \pm 0.019 \mathrm{~d}$ \\
TQ (G3) & $3.23 \pm 0.210 \mathrm{~b}$ & $51.94 \pm 3.297 \mathrm{a}$ & $1.57 \pm 0.049 \mathrm{a}$ & $1.36 \pm 0.028 \mathrm{c}$ \\
TQ+IMI (G4) & $3.58 \pm 0.256 \mathrm{~b}$ & $53.93 \pm 4.327 \mathrm{a}$ & $1.73 \pm 0.058 \mathrm{a}$ & $1.55 \pm 0.065 \mathrm{~b}$ \\
\hline
\end{tabular}

Data are presented as (Mean \pm S.E). S.E: Standard error. $n=6 /$ group

Mean values with different superscript letters in the same column are significantly different at $(\mathrm{P} \leq 0.01)$.

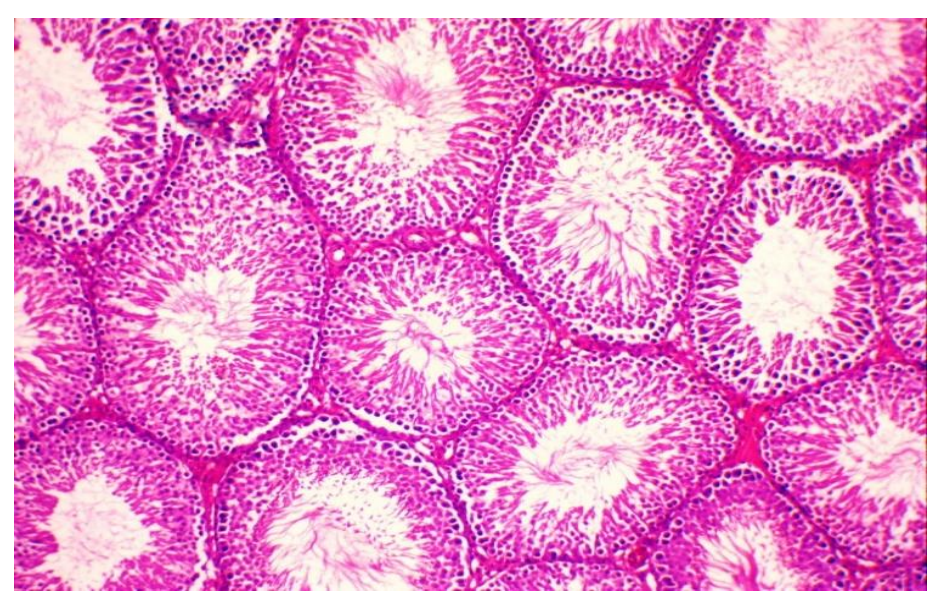

Fig.1. Testes of control rat showing normal histological structures of seminiferous tubules and interstitial tissues. H\&E stain x 100 .

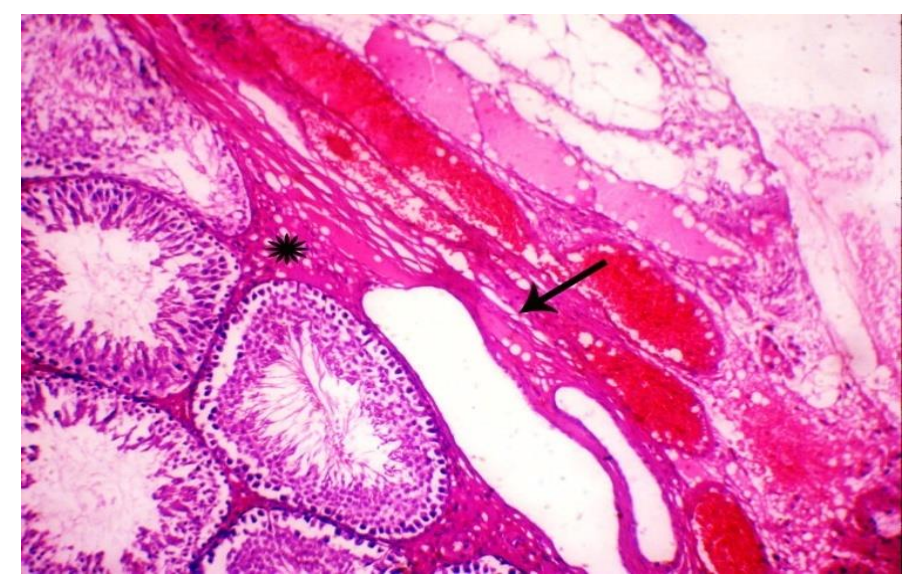

Fig.2. Testes of rat, 8 weeks post administration of IMI (21.2 mg/kg b.w), showing marked increase in the thickness of tunica albuginea (arrow) with sub-capsular edema (asterisk) and severe congestion of sub-capsular blood vessels. H\&E stain x 200. 


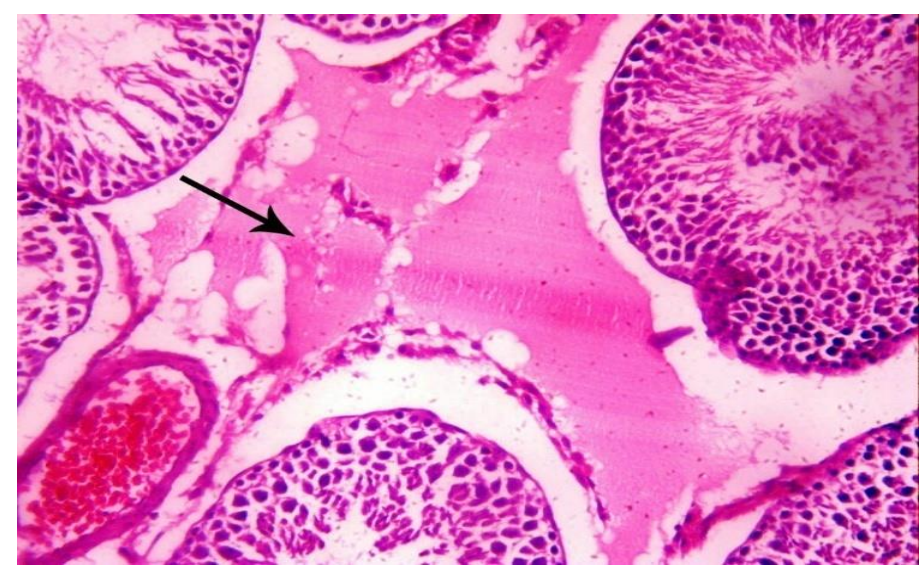

Fig.3. Testes of rat, 8 weeks post administration of IMI (21.2 mg/kg b.w), showing extensive intertubular edema (arrow).H\&E stain x 200.

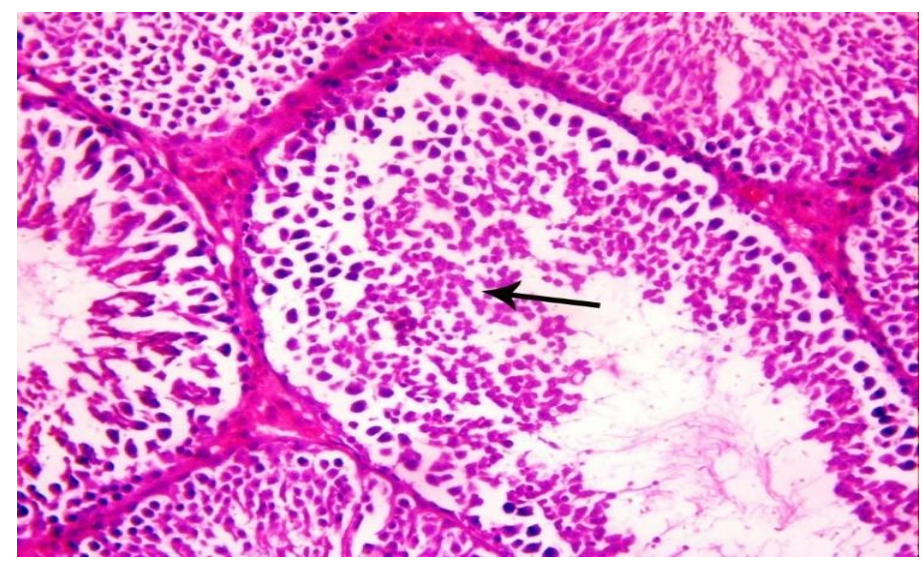

Fig.4. Testes of rat, 8 weeks post administration of IMI ( $21.2 \mathrm{mg} / \mathrm{kg} \mathrm{b.w})$, showing extensive necrosis of spermatogenic cells of seminiferous tubules with stop of spermatogenesis (arrow), H\&E stain $\mathrm{x} 200$.

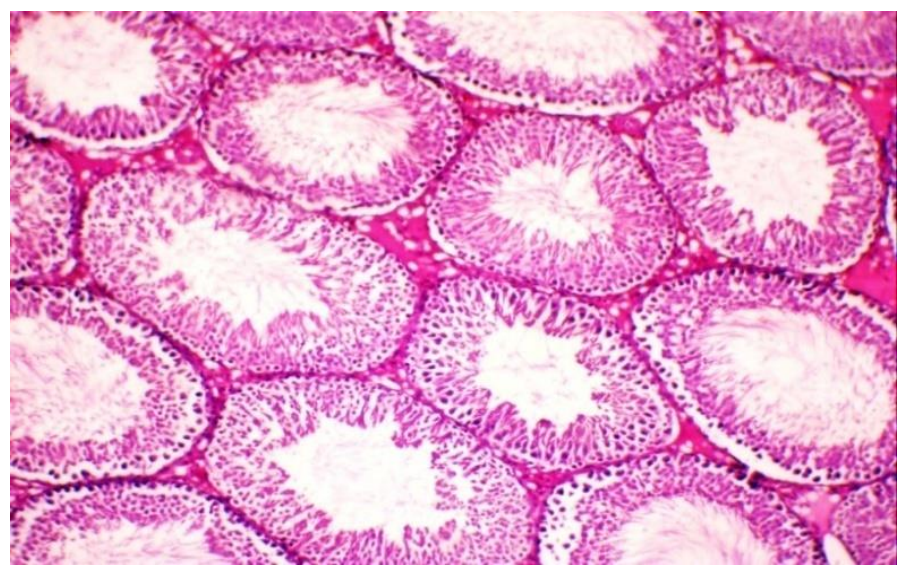

Fig.5. Testes of rat, 8 weeks post administration of TQ (10 mg/ kg b.w /day), showing normal histological structure of the germinal epithelium of seminiferous tubules and interstitial tissues. H\&E stain $\mathrm{x} 100$. 


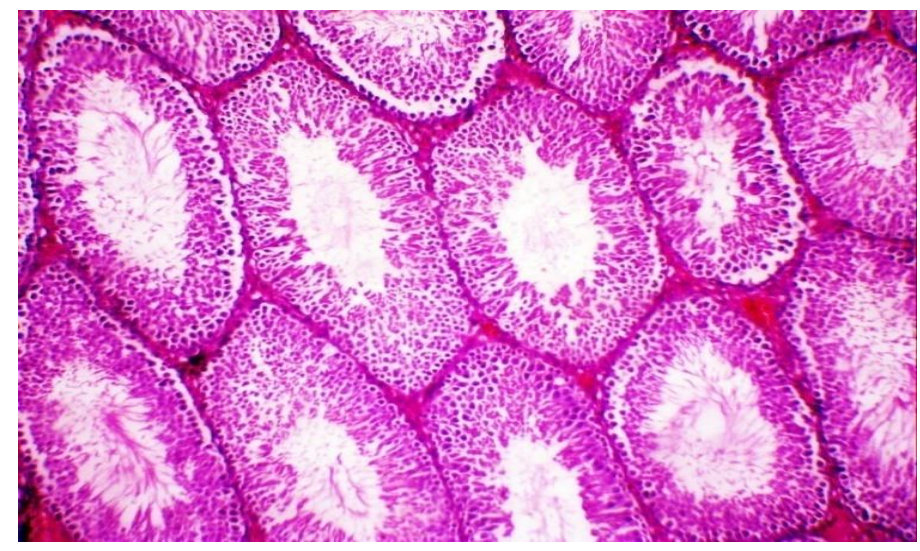

Fig.6. Testes of rat, after daily oral administration with TQ $(10 \mathrm{mg} / \mathrm{kg} \mathrm{b.w} /$ day $)$ for 60 days and 8 weeks post administration of Imidaclopride $(21.2 \mathrm{mg} / \mathrm{kg} \mathrm{b} . \mathrm{w})$ day after day, showing most of the seminiferous tubules were compact with each other. H\&E stain $\mathrm{x} 100$.

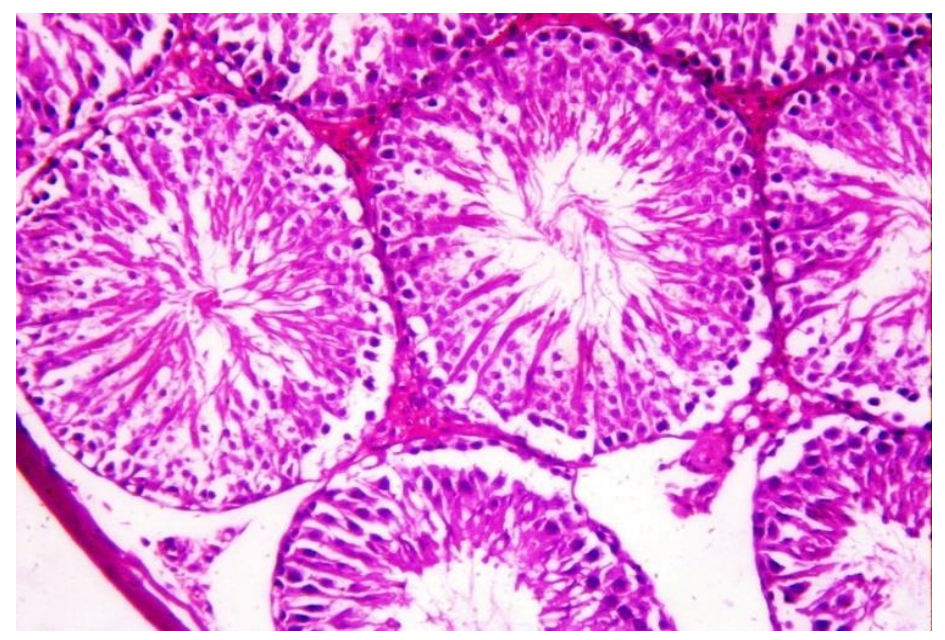

Fig.7. Testes of rat, after daily oral administration with TQ (10 mg/ $\mathrm{kg} \mathrm{b.w} /$ day) for 60 days and 8 weeks post administration of Imidaclopride $(21.2 \mathrm{mg} / \mathrm{kg}$ b.w) day after day, showing Tunica albugenia appeared normal and most of the seminiferous tubules restored its normal structure. H\&E stain

\section{DISCUSSION}

Many pesticides having endocrine disruptor properties and impair the reproductive competence of males, cause adverse effects to the adult reproductive system (Kapoor et al., 2011).Endocrine disruption can take place at different physiological levels: A) altering (inhibiting or stimulating) the secretion of hormones; B) interfering with hormone-receptor interaction as it can act as agonist or antagonist by direct binding to the receptor or by interfering the transductional pathway of a hormone; C) modifying the metabolism of circulating hormones, by increasing or decreasing their excretion rate and or biotransformation in the liver, hepatopancreas or other organs (Rodriguez et al.,2007) .Exposure to IMI has been observed to cause increase in cell death, production of immature sperms and decreased sperm velocity with decrease in serum testosterone in experimental animals (Najafi et al.,2010). Testosterone is responsible for the development of male secondary sex 
characteristics and hormonal imprinting of the liver, prostate and hypothalamus in the prepubertal period and supports spermatogenesis, sperm maturation and sexual function in the adult. For these reasons, the impairment of testosterone biosynthesis may consequently result in reproductive dysfunction (Ewing and Keeney., 1993). The decrease of testosterone levels induced by IMI exposure in G2 (table,1) may indicate that IMI has a direct inhibitory effect on testosterone production from Leydig cells. The administration of IMI may disrupt the biosynthesis of testosterone in Leydig cells because of decreased LH secretion by the pituitary and/or from decreases in steroidogenic enzyme gene transcriptional activity. The disruption of testosterone biosynthesis by IMI consequently may reduce the number of Leydig cells per testis and/or decrease the steroidogenic capacity of individual Leydig cells (Bal et al., 2012). Moreover, Tag El-Din et al. (2003) reported that testosterone level was insignificantly decreased after 3 months dosing period of dicofol while a significant decrease was recorded after 6 months dosing period this may due to pesticide alteration in androgen biosynthesis mediated by cytochrome p-450 system of interstitial cell of the testis, which is required for functioning of $17 \alpha$-hydoxylase \& 17-20- layse ( Fowler et al ., 1987), or induces a variety of hepatic biotransformation enzymes, which are capable of metapolitically transforming androgens into products with low androgen receptor binding activity (Sonderfen et al ., 1987).

The obtained result demonstrated that TQ treatment (G4) insignificantly increased testosterone level. This may be due to TQ stimulation to 17 L-hydroxysteroid dehydrogenase activity thus increasing testosterone level (Gromadzka-Ostrowska et al., 2002). Also, Our results are in agreement with studies of Mukhallad et al.(2009), Gokçe et.al.(2010) and Parandin et al .(2012).

In our study we reported that IMI induction for testicular toxicity $\operatorname{group}(\mathrm{G} 2)$ showed insignificant elevation in E2 when compared with control group. The estrogenic like effects of IMI may produce as a result of pesticides ability to bind estrogen receptors and exhibit estrogenic activity (Stephen, 2001), or by direct exposure to Sertoli cells resulting decrease FSH receptors binding and decrease 3- hydroxyl- steroid- dehydrogenase activity that change estradiol to androgen thus raising estradiol levels (Colborn et al., 1993). Also, it could be attributed to increase the incidence of hypertrophy and/or vacuolation (empty cavities) of adrenal cortex that enhanced the steroidogenic activity (lindane ,1999). This result was supported by Hafez et al. (2016) who reported that E2 levels were markedly elevated after IMI intoxication with different doses (45 and $90 \mathrm{mg} / \mathrm{Kgb} . w$.$) in$ male rats. Also, Tag El-Din et al. (2003) reported dicofol pesticide had an estrogenic effect in male albino rats.

There is a positive association between pesticides exposures and alterations of semen parameters (Yucra et al., 2006). The decrease of epidydimal sperm concentration and increase of abnormal sperm morphology are common observations in the experimental studies with many pesticides (Matsumoto et al., 2008). Sperm count, and sperm abnormality are the prominent factors affecting fertility. Suppressions of gonadotrophins might be an underlying mechanism for the decreased sperm density (Sinha et al.,1995).

The results of this study clearly demonstrated reduction in the sperm motility, viability, count and elevation in sperm 
abnormalities in the IMI intoxicated rats (G2) (table,2). The decrease in sperm motility may be due to low levels of ATP (Bai and Shi, 2002). Toxic effects including reduced sperm motility and concentration with increased abnormal sperm morphology are in agreement with the effects of many other pesticides( Dalsenter et al ., 2003 ). The administration of IMI reduces sperm motility this may be due to decrease in the level of intratesticular testosterone which may lead to detachment of germ cells from seminiferous epithelium and may initiate germ cell/testicular cell apoptosis and degeneration (Blanco-Rodriguez and Martinez-Garcia, 1998). The decrease in epididymal sperm concentration might be due either to the inhibition of testosterone biosynthesis as evident by decreased testosterone levels or to the apoptosis in spermatogenic cells, as demonstrated by increased apoptotic index/seminal DNA fragmentation (kapoor et al., 2011). This leads to low total sperm count, increased sperm abnormalities, histopathologically defective spermatogenesis /lack of spermatogenesis along with testicular changes which were clearly noticed in our study.

The testes, epididymis and other reproductive organs are structurally and physiologically dependent upon the testosterone and other androgens. Testosterone stimulates growth and secretary activity of the reproductive organs, so a significant increase of these hormones could increase the number and function of somatic and germinal cells of testis and in results increase the testis and epididymis weight (O'Donnel et al.,1994). Gokce et al. (2010) has been confirmed that Thymoquinone treatment has protective effects on testicular parameters. Mohammad et al. (2009) showed that supplementation of TQ in mice significantly increased sperm motility and Al-Zahrani et al. (2012) has also shown that TQ increase the sperm quality of mice. LH stimulates the production of testosterone in Leydig cells, which in turn may act on the Sertoli and peritubular cells of the seminiferous tubules and indirectly stimulates spermatogenesis via testosterone.

Zohra et al. (2012) treated diabetic rats by adding $2 \%$ Nigella sativa seeds to their diet for 30 days. This addition improved testosterone levels and testis tissue, semen quantity and mobility, and it reduced blood glucose and oxidative stress parameters.

(ROS) are generated continuously in small amounts in normal cells as they are essential for many biological functions (Suzuki et al.,1997) and it mediate many toxin-induced testicular injuries (Gultekin et al., 2000). Interaction of ROS with cellular membrane results in membrane lipid peroxidation which can be measured by using MDA, which is a marker of oxidative lipid damage and a major oxidative product of peroxidized polyunsaturated fatty acids (Zhang et al., 2004). Enzymes such as SOD and CAT play an important role in the elimination of ROS produced during the biotransformation of xenobiotics and the induction of the SOD/CAT system may be the first defense mechanism against ROS (Lushchak, 2016).

According to our finding, IMI had exerted oxidative stress in the testicles group $(\mathrm{G} 2)$ \& (table .3) which showed that, IMI induced rats (G2) showed a significant increase in testicular MDA and decrease in GSH, SOD and CAT levels when compared to normal control group. These results are nearly similar to (Bal et al., 2012) who reported that the levels of testis MDA (P < $0.05)$ were significantly higher and those of GSH significantly $(\mathrm{P}<0.001)$ lower in the rats treated with $8 \mathrm{mg} / \mathrm{kg}$ IMI than that in the 
controls. Also, Mohany et al. (2011) who demonstrated a significant increase in liver MDA activity in the IMI-treated male albino rats compared to the control group, with the highest levels recorded in the 1st and 3rd weeks.

In general, the inhibition of CAT activity has been related to the binding of toxicants to -SH groups of enzymes, increased $\mathrm{H} 2 \mathrm{O} 2$ and/ or superoxide radical (Ruas et al., 2008). The decrease activities of SOD, CAT and GSH content together with increase LPO may be attributed to induce free radicals in imidacloprid treated rats. Kapoor et al. (2010) had indicated that imidacloprid did not induce oxidative stress at 5 and $10 \mathrm{mg} / \mathrm{kg} \mathrm{b}$.w/day to female rats when exposed for 90 days. However, imidacloprid at $20 \mathrm{mg} / \mathrm{kg}$ b.w,/day had significantly induced oxidative stress to female rats. This may be due to dearrangement of cellular oxidative status as evidenced by increased level of LPO (MDA), decreased activities of CAT, SOD, and reduced GSH level in vital tissues.

Levels of ROS production by sperm correlate negatively with sperm quality in the original semen. The link between poor sperm quality and increased ROS generation lies in the retention of excess residual cytoplasm (cytoplasmic droplets) in abnormal spermatozoa. When spermatogenesis is impaired, the cytoplasmic extrusion mechanisms are defective (Huszar et al.,1997).

Thymoquinone, the major active constituent of Nigella sativa, could prevent the increase in the myeloperoxidase Activity (Gokçe et.al., 2010). The obtained result showed that TQ administration to IMI intoxicated male rats (G4) caused a marked decrease in testicular MDA (table, 3) when compared with IMI intoxicated rats (G2), while there was a marked elevation in testicular tissue SOD, Catalase and GSH. These results confirmed by Singh et al, (2014) who illustrated the ability of TQ to improve antioxidant defense. Al Wafai et al. (2013) reported that TQ could suppress cyclooxygenase- 2 enzyme expression and lipid peroxidation and raise SOD levels in rats.

These results were confirmed by histopathological observation since IMI rat testes (G2) under microscopical examination revealed marked increase in the thickness of tunica albuginea with sub-capsular edema and severe congestion of sub-capsular blood vessels. Also, extensive necrosis of spermatogenic cells with stop of spermatogenesis,

Moreover, after TQ protection to IMI rats (G4) revealed less prominent histopathological changes when compared with IMI group as, tunica albuginea appeared normal, most of the seminiferous tubules were compact with each other. The spermatogenic layers appeared somewhat normal in most tubules and seminiferous tubules restored its normal structure and the spermatogenesis processes are normal. These data was confirmed by Atta et al. (2017) who demonstrated that TQ treatment to diabetic rats in Cross sections of histopathological examination of testicular samples, showed resuscitation of the seminiferous tubules enhancement $(100 \times)$ in the tubular basal compartment with the presence of spermatogonia.

\section{CONCLUSION}

Thymoquinone treatment exerted a protective effect against reproductive dysfunction induced by IMI Intoxication not only through its powerful antioxidant effect but also through its protective remedy against the inflammatory effects of testicular toxicity. 
Oxidative damage induced in the testicular tissues of IMI intoxicated rats is evidenced by the impairment in hormonal determination ,sperm quality and antioxidant determination at testicular tissues. TQ is considered as an excellent natural protective agent that has the ability to ameliorate the toxic effect of IMI by restoring all the affected parameters to near its normal levels and relieve the degenerative changes of the testicular tissues. The deleterious effect of IMI was improved by TQ, which was proven by restoration of seminiferous tubules with active Leydig cells. So, these results confirmed the strong antioxidant, anti-inflammatory effects of TQ in testicular Toxicity.

\section{REFERRENCES}

Aebi, H. 1984. Catalase in vitro assay methods. Methods in Enzimology. 105:121-126.

Ahmad, A., Husain, A., Mujeeb, M., Khan, S. A., Najmi, A. K., Siddique, N. A., Damanhouri, Z.A. and Anwar, F.2013.A review on therapeutic potential of Nigella sativa: A miracle herb. Asian Pacific J. Tropical Biomed. 3: 337-352.

Al Wafai, R. J.2013. Nigella sativa and thymoquinone suppress cyclooxygenase-2 and oxidative stress in pancreatic tissue of streptozotocin-induced diabetic rats. Pancreas. 42(5): 841-849.

Ali, B.H. and Blunden, G.2003. Pharmacological and toxicological properties of Nigella sativa. Phytotherapy Res.17: 299-305.

Al-Zahrani, S., Mohany, M., Kandeal, S. and Badr, G. (2012). Thymoquinone and Vitamin E supplementation improve the reproductive characteristics of heat stressed male mice. Journal of Medicinal Plants Research, 6(3): 493-499.

Atta M.S., Almadaly, E.A., El-Far, A.H., Saleh R. M., Assar, D.H., Al Jaouni, S. K. and Mousa, S. A.2017.Thymoquinone Defeats Diabetes-Induced Testicular Damage in Rats Targeting Antioxidant, Inflammatory and Aromatase Expression.

int. Jornal of. Molecular. Science. 18, 919.

Badary, O.A., Abdel-Naim, A.B., AbdelWahab, M.H. and Hamada, F.M.2000. The influence of thymoquinone on doxorubicininduced hyperlipidemic nephropathy in rats. Toxicology. 143: 219-226.

Bai, J. P. and Shi, Y.L.2002. Inhibition of Ca (2+) channels in mouse spermatogenic cells by male antifertility compounds from $\mathrm{T}$. ripterygium wilfordii Hook. f. Contraception. 65(6): 441-445.

Bal, R., Naziroğlu, M., Türk, G., Yilmaz, Ö., Kuloğlu, T., Etem, E., and Baydas,G.2012.Insecticide imidacloprid induces morphological and DNA damage through oxidative toxicity on the reproductive organs of developing male rats. Cell BiochemFunct. 30(6):492-499.

Berny, P.J., Buronfoss, F., Videmann, B., Buronfosset, T. 1999. Evaluation of the toxicity of imidacloprid in wild birds. A new high performance thin layer chromatography method for the analysis of liver and crop samples in suspected poisoning cases. J 
LiqChromRel Technol. 22: 15471559.

Blanco-Rodriguez, J. and Martinez-Garcia, C. 1998. Apoptosis precedes detachment of germ cells from the seminiferous epithelium after hormonal suppression by short-term oestradiol treatment of rats. Int $\mathbf{J}$ Androl. 21:109-115.

Burns, M.M. 2000. Alternative medicine: Herbal preparation. Clin Ped Emerg Med. 1: 186-190.

Colborn, T., Fredrick, S., Vomsaal, F. S. and Soto, A. M. 1993. developemental effects of endocrine - disrupting chemicals in wildlife and humans. Enviro. Health perspectives.101:378381.

Dalsenter, P.R., de Araujo, S.L., de Assis, H.C., Andrade, A.J., Dallegrave, E.2003. Pre and postnatal exposure to endosulfan in Wistar rats. Hum Exp Toxicol. 22(4): 171-175.

D'Cruz, S.C., Vaithinathan, S., Jubendradass, R. andMathur, P.P.2010. Effects of plants and plant products on the testis. Asian J Androl. 12: 468-479.

Dray, T. and Walling, S. 1976. Conleton's

Histopathological Technique. University Press, London, Oxford, pp: 114-118.

El-Dakhakhny, M., Madi, N.J., Lembert, N. and Ammon, H.P.2002. Nigella sativa oil, nigellone and derived thymoquinone inhibit synthesis of 5lipoxygenase products in polymorphonuclear leukocytes from rats. J. Ethnopharmacology. 81:161164.

EL-Gendy, K.S., Aly, N.M., Mahmoud, F.H., Kenawy, A. and El-Sebae, A.K.
2010. The role of vitamin $\mathrm{C}$ as antioxidant in protection of oxidative stress induced by imidacloprid. Food Chem. Toxicol. 48: 215-221.

Ergüder, B., Avci, A., Devrim, E. and Durak, I. 2007.Effects of cooking techniques on antioxidant enzyme activities of some fruits and vegetables. Turk $\mathbf{J}$ Med Sci. 37(3):151-156.

Evans, G.and Maxwell, W.M.C. 1987. Handling and examination semen. In: Maxwell WMC (ed.): Salamon's Artificial Insemination of Sheep and Goat. Butterworths, Sydney. 93-106.

Ewing, L.L. and Keeney, D.S.1993. Leydig cells: structure and function. In Cell and Molecular Biology of the Testis, Desjardins C, Ewing LL (eds.). Oxford University Press. 137-165.

Fowler, A., Mistry, P.and Goering, L.1987. Mechanisms of metal-induced cell injury. Res. Comm. Chem. Pharmacol., 28: 689.

Gali-Muhtasib, H., EL-Najjar, N. and Schneider-Stock, R.2006. The medicinal potential of black seed (Nigella Sativa) and its components. AdvPhytomed. 2:13353.

Gokçe, A., Oktar, S., Koc, A., Gonenci, R., Yalcinkaya, F., Yonden, Z. and Duru,M. 2010 . Protective Effect of Thymoquinone in Experimental Testicular Torsion. Eur Urol. 85:461465.

Gokce, A., Oktar, S., Koc, A. and Yonden, Z. 2011. Protective effects of thymoquinone against methotrexateinduced testicular injury. Hum. Exper. Toxicol. 30: 897-903. 
Gromadzka-Ostrowska, J., Przepiorka, M. and Romanowicz, K.2002. Influence of dietary fatty acids composition, level of dietary fat and feeding period on some parameters of androgen metabolism in male rats. Reprod. Biol. 2: 277-293.

Gultekin, F., Ozturk, M., Akdogan, M. 2000. The effect of organophosphate insecticide chlorpyrifos-ethyl on lipid peroxidation and antioxidant enzymes (in vitro). Arch Toxicol. 74(9): 533-538.

Hafez, E.M., Issa, S.Y., AI-Mazroua, M.K., Ibrahim, K.T., Rahman, S.M.A. 2016. The Neonicotinoid Insecticide Imidacloprid: A Male Reproductive System Toxicity Inducer-Human and Experimental Study. Toxicol open access 2: 109.

Hakeem, K. R., Mahmood, I., Imadi, S.R., Shazadi, K. and Gul,A. 2016. In book: Plant, Soil and Microbes: Implications in Crop Science, Chapter: Effects of Pesticides on Environment, Publisher: Springer International. (1): 253-269.

Haseena, S., Manjunath, A., Kusal, K .D., Shaik, H.S.2015.Effect of Nigella Sativa Seed Powder on Testosterone and LH levels in Sterptozotocine Induced Diabetes male Albino Rats. J. Pharm. Sci.\&Res.7(4):234-237.

Huszar, G., Sbracia, M. and Vigue, L.1997. Sperm plasma membrane remodeling during spermiogenic maturation in men: relationship among plasma membrane beta 1 ,4galactosyltransferase, cytoplasmic creatine phosphokinase and creatine phosphokinase isoform ratios. Biol Reprod. 56: 1020-1024.
Ismail, M., Al-Naqeep, G. and Chan, K.W.2010. Nigella sativa thymoquinone-rich fraction greatly improves plasma antioxidant capacity and expression of antioxidant genes in hypercholesterolemic rats. Free Radical Biology Med. 48: 664-672.

Kapoor, U., Srivastava, M.K., Bhardwaj, S., Srivastava, L.P. 2010. Effect of imidacloprid on antioxidant enzymes and lipid peroxidation in female rats to derive its NO Observed Effect Level (NOEL). J. Toxicol. Sci. 35: 577-81.

Kapoor, U., Srivastava, M.K. and Srivastava, L.P. 2011. Toxicological impact of technical imidacloprid on ovarian morphology, hormones and antioxidant enzymes in female rats. Food and Chemical Toxicology. 49 :3086-3089

Lindane, B. 1999. The article on dicofol. Pesticides News. (43): 20-21.

Lushchak, V.I. 2016. Contaminant-induced oxidative stress in fish: a mechanistic approach. Fish Physiol. Biochem. 42: 711-747.

Matsuda, K., Buckingham, S.D., Kleier, D., Rauh, J.J., Grauso, M. and Satelle, D.B. 2001. Neonicotinoids: insecticides acting on insect nicotinic acetylcholine receptors. Trends Pharmacol Sci. 22: 573- 580.

Matsumoto, M., Hirose, A. and Ema, M. 2008. Review of testicular toxicity of dinitrophenolic compounds, 2-secbutyl-4,6-dinitrophenol, 4,6-dinitroocresol and 2,4-dinitrophenol. Reprod. Toxicol. 26: 185-190. 
Mesbah, L., Soraya, B., Narimane, S. and Jean, P.F. 2004. Protective effect of flavonides against the toxicity of vinblastine cyclophosphamide and paracetamol by inhibition of lipid peroxydation and increase of testicular glutathione. Haematol,7. (1): 59-67.

Mizzel, R.F. and Sconyers, M. C. 1992. Toxicology of imidocloprideto selected arthropod predators in laboratory. FlorEntomol. 75:277-280.

Mohammad, M.A., Mohamad, M.M. and Dradka, H. 2009. Effects of black seeds (Nigella sativa) on spermatogenesis and fertility of male Albino rats. Research Journal of Medicine and Medical Sciences. 4 (2): 386-390.

Mohany,M., Badr.G ., Refaat . I .and El-Feki, M. 2011. Immunological and histological effects of exposure to imidacloprid insecticide in male albino rats. African Journal of Pharmacy and Pharmacology. 5(18): 2106-2114.

Mukhallad, A., Mohamad, M. and Darka, H.2009. Effects of black seeds (Nigella sativa) on spermatogenesis and fertility of male albino rats. Res. J. Medicine Med. Sci.4: 386-390.

Nagi, M.N. and Mansour, M.A.2000. Protective effect of thymoquinone against doxorubicin-induced cardiotoxicity inrats: a possible mechanism of protection. Pharmacol. Res. 41:283-289.

Najafi, G., Razi, M., Hoshyar, A., Feyzi, S., Shahmohamadloo, S. and Feyzi, S.. 2010. The effect of chronic exposure with imidacloprid insecticide on fertility in mature male rats. Int $\mathbf{J}$ FertilSteril 4: 9- 16.

Nishikimi, M., Appaji, N. and Yagi, K. 1972. The occurrence of superoxide anion in the reaction of reduced phenazine methosulfate and molecular oxygen. Biochem Biophys Res Commun.46:849-854.

O’Donnel, L., McLachlan, R.I., Wreford, N.G. and Robertson, D.M.1994. Testosterone promotes the conversion of round spermatids between stages vii and viii of the rat spermatogenic cycle. Endocrinology. 135: 2608-614.

Parandin, R., Yousofv, N. and, Ghorbani, R. 2012. The enhancing effects of alcoholic extract of Nigella sativa seed on fertility potential, plasma gonadotropins and testosterone in male rats. Iran J Reprod Med. 4:355362.

Rodriguez, E. M., Medesani, D. A. and Finerman, M. 2007. Endocrine disruption in crustaceans due to pollutants; A review. Comp. Biochem. Physiol., part A, 146: 661671.

Ruas, C.B., Carvalho, C.S., Araujo, H.S., Espindola, E.L. and Fernandes, M.N. 2008. Oxidative stress biomarkers of exposure in the blood of cichlid species from a metal-contaminated river. Ecotoxicol. Environ. 71: 86-93.

SAS. 2008. Statistical analysis system: User s guide v. 9.2, Inst. Inc., Cary N.C., USA.

Sharma, R. K.and Goyal, A. K. 2014. Agropesticides and andrology, International Journal of Pharmacy and Pharmaceutical Sciences .6 (10). 
Singh, R., Devi, S. and Gollen, R.2014. Role of free radical in atherosclerosis, diabetes and dyslipidemia. Diabetes/metabolism research and reviews .13(1):42-49.

Sinha, N., Narayan, R., Shanker, R. and Saxena, D.K. 1995. Endosulfan induced biochemical changes in the testis of rats.Vet. Hum. Toxicol. 37: 547-549.

Sonderfen, A.J., Arlotto, M. P., Dutton, D. R., Mcmillen, S.K. and Parkinson, A. 1987. Regulation og testosterone hydroxylation by rat liver microsomal cytochrome P-450. Arc. Biochem. Biophys. 255:27-41.

Sönmez, M., Türk, G. and Yüce, A.2005.The effect of ascorbic acid supplementation on sperm quality, lipid peroxidation and testosterone levels of male Wistar rats. Theriogenology. 15;63(7):20632072.

Stephan,H. 2001. Hydroxylated polychlorinated Biphenyls (PCBs) and Organochlorine pesticides as potential endocrine disruptors. the handbook of Environn. Chemis.3: 155-160.

Suzuki, Y. J., Forman, H. J. and Sevanian, A. 1997.

Oxidants as stimulators of signal transduction. Free Radical Biology \&Medicine. 22 (1-2) :269-285.

Tag El-Din, H. A., Abbas, H.E. and Elkashoury, A. A. 2003. Experimental studies of dicofol reproductive toxicity on male albino rats. Bull Fac. Pharm. Cairo Univ. 41(2).

United States. Environmental Protection Agency (EPA) .1995. Imidacloprid; evaluation of toxicity data submitted and identification of outstanding toxicology data requirements. I.D. Nos.: 00315ULL,5E0445. Tox. Chem. No: 497E

Uz, E., Bayrak, O., Uz, E., Kaya, A., Bayrak, R., Uz, B. and Turgut, F.H. 2008.Nigella sativa oil for prevention of chronic cyclosporine nephrotoxicity: an experimental model. Am., J. Nephrol. 28:517-522.

Wyrobek, A.J., Gordon, L.A., Burkhart, J.G., Francis, M.W. , Letz, G., Malling, H.V., Topham, J. C. and Whorton, M.D. 1983. An evaluation of the mouse sperm morphology test and other sperm tests in nonhuman mammals. A report of the U.S. Environmental Protection Agency Gene-Tox Program. Mutat Res. 115(1):1-72.

Yokoi, K., Uthus, E.O. and Nielsen, F.H.2003. Nickel deficiency

diminishes sperm quantity and movement in rats. Biol Trace Elem Res. ,93(1-3):141-154.

Yucra ,S., Rubio, J., Gasco, M., Gonzales, C., Steenl and, K. and Gonzales, G.F. 2006. Semen quality and reproductive sex hormone levels in Peruvian pesticide sprayers. Int $\mathbf{J}$ Occup Environ Health. 12: 355-361.

Zhang, Y.T., Zheng, Q.S., Pan, J., Zheng, R.L. 2004. Oxidative damage of biomolecules in mouse liver induced by morphine and protected by antioxidants. Basic Clin. Pharmacol. Toxicol. 95: 53-58

Zohra, G., Khaled, H., Mongi, S., Zouheir, S., Khaled,

M.

Z., 
Abdelfattah, E. F. and Ahmed, H.

Effect of Nigella sativa seeds on reproductive system of male diabetic

rats. African Journal of

Pharmacy and Pharmacology 2012;

6(20): 1444-1450. 